\title{
Correction to: Probing the protein corona around charged macromolecules: interpretation of isothermal titration calorimetry by binding models and computer simulations
}

\author{
Xiao Xu ${ }^{1} \cdot$ Joachim Dzubiella ${ }^{2,3}$ \\ Published online: 4 September 2021 \\ (c) The Author(s) 2021 \\ Correction to: Colloid and Polymer Science (2020) 298:747-759 \\ https://doi.org/10.1007/s00396-020-04648-x
}

The article Probing the protein corona around charged macromolecules: interpretation of isothermal titration calorimetry by binding models and computer simulations, written by Xiao Xu and Joachim Dzubiella, was originally published Online First without Open Access. After publication in volume 298, issue 7, page 747-759 the author decided to opt for Open Choice and to make the article an Open Access publication. Therefore, the copyright of the article has been changed to (C) The Author(s) 2020 and the article is forthwith distributed under the terms of the Creative Commons Attribution 4.0 International License, which permits use, sharing, adaptation, distribution and reproduction in any medium or format, as long as you give appropriate credit to the original author(s) and the source, provide a link to the Creative Commons licence, and indicate if changes were made. The images or other third party material in this article are included in the article's Creative Commons licence,

The original article can be found online at https://doi.org/10.1007/ s00396-020-04648-x.

Xiao Xu

xuxiao@njust.edu.cn

Joachim Dzubiella

joachim.dzubiella@physik.uni-freiburg.de

1 School of Chemical Engineering, Nanjing University of Science and Technology, 200 Xiao Ling Wei, Nanjing 210094, People's Republic of China

2 Applied Theoretical Physics-Computational Physics, Physikalisches Institut, Albert-Ludwigs-Universität Freiburg, Hermann-Herder-Str. 3, 79104 Freiburg, Germany

3 Research Group for Simulations of Energy Materials, Helmholtz-Zentrum Berlin für Materialien und Energie, Hahn-Meitner-Platz 1, 14109 Berlin, Germany unless indicated otherwise in a credit line to the material. If material is not included in the article's Creative Commons licence and your intended use is not permitted by statutory regulation or exceeds the permitted use, you will need to obtain permission directly from the copyright holder. To view a copy of this licence, visit http://creativecommons. org/licenses/by/4.0.

Funding Open access funding enabled and organized by Projekt DEAL.

Open Access This article is licensed under a Creative Commons Attribution 4.0 International License, which permits use, sharing, adaptation, distribution and reproduction in any medium or format, as long as you give appropriate credit to the original author(s) and the source, provide a link to the Creative Commons licence, and indicate if changes were made. The images or other third party material in this article are included in the article's Creative Commons licence, unless indicated otherwise in a credit line to the material. If material is not included in the article's Creative Commons licence and your intended use is not permitted by statutory regulation or exceeds the permitted use, you will need to obtain permission directly from the copyright holder. To view a copy of this licence, visit http://creativecommons.org/licenses/ by/4.0/.

Publisher's Note Springer Nature remains neutral with regard to jurisdictional claims in published maps and institutional affiliations. 